\title{
"Enterprise Resource Planning (ERP) systems success: impact of employees' perceptions and satisfaction on expected benefits in a manufacturing setting"
}

\begin{tabular}{|c|c|}
\hline AUTHORS & $\begin{array}{l}\text { Vukani Cosmos Xulu iD https://orcid.org/0000-0001-8864-5492 } \\
\text { Sachin Suknunan (D https://orcid.org/0000-0002-7296-8059 }\end{array}$ \\
\hline ARTICLE INFO & $\begin{array}{l}\text { Vukani Cosmos Xulu and Sachin Suknunan (2020). Enterprise Resource } \\
\text { Planning (ERP) systems success: impact of employees' perceptions and } \\
\text { satisfaction on expected benefits in a manufacturing setting. Problems and } \\
\text { Perspectives in Management, 18(2), 466-475. doi:10.21511/ppm.18(2).2020.38 }\end{array}$ \\
\hline DOI & http://dx.doi.org/10.21511/ppm.18(2).2020.38 \\
\hline RELEASED ON & Monday, 06 July 2020 \\
\hline RECEIVED ON & Wednesday, 25 March 2020 \\
\hline \multirow[t]{2}{*}{ ACCEPTED ON } & Friday, 29 May 2020 \\
\hline & $(\mathrm{cc}) \mathrm{BY}$ \\
\hline LICENSE & $\begin{array}{l}\text { This work is licensed under a Creative Commons Attribution } 4.0 \text { International } \\
\text { License }\end{array}$ \\
\hline JOURNAL & "Problems and Perspectives in Management" \\
\hline ISSN PRINT & $1727-7051$ \\
\hline ISSN ONLINE & $1810-5467$ \\
\hline PUBLISHER & LLC "Consulting Publishing Company "Business Perspectives" \\
\hline FOUNDER & LLC "Consulting Publishing Company "Business Perspectives" \\
\hline & $\begin{array}{l}\text { E-: } \\
\text { =-:- }\end{array}$ \\
\hline NUMBER OF REFERENCES & NUMBER OF FIGURES \\
\hline 27 & 4 \\
\hline
\end{tabular}

(C) The author(s) 2022. This publication is an open access article. 


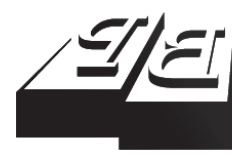

\section{BUSINESS PERSPECTIVES}

(O)

LLC "CPC "Business Perspectives" Hryhorii Skovoroda lane, 10, Sumy, 40022, Ukraine www.businessperspectives.org

Received on: $25^{\text {th }}$ of March, 2020 Accepted on: $2^{\text {th }}$ of May, 2020 Published on: $6^{\text {th }}$ of July, 2020
(C) Vukani Cosmos Xulu, Sachin Suknunan, 2020

Vukani Cosmos Xulu, MBA, Graduate School of Business and Leadership, University of KwaZulu-Natal, Durban, South Africa.

Sachin Suknunan, Doctor of Business Administration, Student Services Division, University of KwaZulu-Natal, Durban, South Africa. (Corresponding author)

\section{ENTERPRISE RESOURCE} PLANNING (ERP) SYSTEMS SUCCESS: IMPACT OF EMPLOYEES PERCEPTIONS AND SATISFACTION ON EXPECTED BENEFITS IN A MANUFACTURING SETTING

\begin{abstract}
The benefits that Enterprise Resource Planning (ERP) systems can offer organizations are the primary reason behind their popularity. However, employees' satisfaction is one of the factors that affect ERP system benefits, while employees' expectations of such systems affect their satisfaction. The study aimed to identify and investigate how employees' expectations of the general benefits from ERP systems influence employees' satisfaction and actual benefits derived. The study was performed in a manufacturing organization, and data collection entailed a quantitative questionnaire, targeting an entire population of 80 employees (ERP users). The study obtained a $66 \%$ response rate, and quantitative data analysis techniques were used. The study found out that users with high expectations were more dissatisfied and not benefiting from the ERP system compared to those with low expectations. Users with more experience did not find the ERP system very challenging compared to the users who had less experience. The Chi-square test of independence implied that the general expectations that users had on ERP systems did not affect their satisfaction (7.965, $\mathrm{p}=0.241)$. Besides, there was a relationship between general expected benefits from an ERP system and the actual benefits of using it $(19.342, \mathrm{p}<0.013)$. Furthermore, a moderate and significant relationship between actual benefits derived and user satisfaction was found $\left(.451^{* *}, p\right.$ $<0.001)$. The study concludes that there is a relationship between employees' expected benefits, employees' satisfaction, and actual benefits derived from ERP systems.
\end{abstract}

Keywords users, relationship, actual, influence, business

\section{JEL Classification $\quad$ M15, D25, E22}

\section{INTRODUCTION}

The Enterprise Resource Planning (ERP) system is a computer-based tool capable of unifying various business processes and structuring the information into an advanced data structure entity (Abd Elmonem, Nasr, \& Geith, 2016; Kadir, Ismail, \& Yatin, 2015). An ERP system is seen as a method of systematizing the storage and use of relevant company data through computerized elements. Enterprise Resource Planning systems are expected to be applied as planning systems; however, many researchers believe that these are only for automating enterprise systems (Badewi, Shehab, Zeng, \& Mohamad, 2017). As a result, while ERP systems can be effective planning tools, they could also be used for other purposes, including the analysis of data that can facilitate daily decision-making to avoid negative business outcomes or take advantage of daily opportunities that can present themselves dynamically. However, for ERP to work, it is imperative that employ- 
ees who are ERP users must be satisfied with the system to utilize it effectively, which can, in turn, derive the necessary benefits for the organization (Al-Jabri \& Roztocki, 2015; Delone \& McLean, 2003; Venkataiah, 2012).

\section{LITERATURE REVIEW}

The exponential growth of ERP systems usage results from the desired business benefits that are generally expected from these software systems due to their growing popularity (Badewi \& Shehab, 2016; Esteves, 2009; Al-Jabri \& Roztocki, 2015; Al-Jabri, 2015; Kadir, Ismail, \& Yatin, 2015; Teittinen, Pellinen, \& Järvenpää, 2013). This popularity of ERP systems is driven by its technological capability that enables businesses to sustain high performance through enhancing professionalism, quality, good service delivery, and competitive advantage (Kanellou \& Spathis, 2013; Al-Jabri, 2015; Kadir, Ismail, \& Yatin, 2015). The need for sustainability and competitive advantage has played a role in many businesses desiring to adopt ERP systems (Al-Jabri, 2015). The desire for ERP benefits by businesses in general is, therefore, expressed and is a result of the motivation to study the concepts and mechanisms entailed in benefiting from ERP systems. Towards the end of the $20^{\text {th }}$ century, ERP systems have become more popular; however, they are still complex and, therefore, present many challenges before businesses can use them properly (May, Dhillon, and Caldeira, 2013). The challenges that may appear with the adoption of an ERP system can result in business failure. Therefore, it is necessary to understand these challenges to minimize their impact. In support of this, Maier, Laumer, and Weinert (2015) also concluded that complexity is one of the key challenges of ERP systems. They obtained such a finding through a study on ERP system characteristics that caused stress and exhaustion to employees.

The extent to which a business will benefit from the adoption of an ERP system is highly dependent on whether users are satisfied with the system (Al-Jabri \& Roztocki, 2015; Delone \& McLean, 2003). The attitude of a user towards a product has been historically used in social psychology and other behavioral studies to determine the success of the product, and it is the main construct that defines user satisfaction (Vaezi, Mills, Chin, \& Zafar, 2016). User satisfaction comprises the experience the user has with an ERP system compared to the best experience they have conceptualized in their mind (Shan, Li, Yao, Shi, \& Ren, 2014). The success of an ERP system is determined by user satisfaction (Aggelidis \& Chatzoglou, 2012; Delone \& McLean, 2003). To deliver products or services that satisfy customers, companies should first provide an IT system that satisfies employees (Shan, Li, Yao, Shi, \& Ren, 2014). Therefore, user satisfaction is one of the concepts that can allow understanding of ERP system benefits. The user's collection of expectations concerning the system they use will affect their satisfaction (Venkataiah, 2012) while user satisfaction influences usage and actual ERP benefits derived (Al-Jabri \& Roztocki, 2015; Delone \& McLean, 2003). This points out to the possibility of user expectations affecting user satisfaction and, therefore, the benefits derived from ERP systems.

The adoption of ERP systems is driven by the positive expectations that these systems will enhance the performance and status quo of the organizations implementing them (Kanellou \& Spathis, 2013). As a result, many companies are investing large financial resources because they are motivated by expectations that the ERP system will improve its competitive advantage (Mitakos, Almaliotis, \& Demerouti, 2010). However, expectations are not the same across industries and different employee levels and personalities (Shan, Li, Yao, Shi, \& Ren, 2014). Managers expect ERP systems to improve strategic abilities, while other employees may expect an ERP system to improve functional areas they are positioned in (Teittinen, Pellinen, \& Järvenpää, 2013). Companies adopting the ERP system are required to understand if or how these differences may influence the expected outcomes due to the differences in employee profiles and expectations. Mitakos, Almaliotis, and Demerouti (2010) believed that the more prospective ERP users expect from the ERP system, the more they will benefit and be satisfied. They further explained that when ERP system exceeds the user's expectations, the user would be more satisfied by the system. Therefore, the ERP system designers have a challenge of exceeding the expectations of ERP systems users with different expectations, and for them to 
be able to produce these results, they need to understand ERP user expectations.

The DeLone and McLean Information Systems success model (Al-Jabri \& Roztocki, 2015; Delone \& McLean, 2003) was used to develop the conceptual framework model that guided the research. The DeLone and McLean IS success model (Delone \& McLean, 2003) was initially developed in the late $20^{\text {th }}$ century, and it has been referred to by many scholars (Rana, Dwivedi, Williams, \& Weerakkody, 2015; Salahuddin \& Ismail, 2015; Dwivedi, 2015; Steinhueser, Richter, \& Smolnik, 2015). It has been updated 10 years later (2003) by DeLone and McLean, and after that it was found to be relevant and effective also in the $21^{\text {st }}$ century (Delone \& McLean, 2003).

To investigate the relationship between the user expectations of general benefits with user satisfaction and with the actual benefits derived from using ERP systems, the measurement of general expected benefits (g_exp_benefits), user satisfaction (satisfaction) and actual benefits derived (actual_benefits) was necessary. The variable g_exp_benefits is independent, while the variables satisfaction and actual_benefits are dependent. The DeLone and McLean IS success model was applied; however, only the variables that were relevant to this study were utilized from the model. A new independent variable had to be introduced into the model, and that was the 'general benefits' expected by the ERP system users. This is shown in the conceptual framework in Figure 1.
Figure 1 is based on the premise that users' expectations of general benefits from the ERP system and user satisfaction with the ERP system can influence the actual benefits derived from the ERP system.

Based on the literature outlined, the need to study user satisfaction and expectation is clearly revealed by the impact these elements have on ERP benefits. Substantial research that has been done on ERP system success places emphasis on the actual benefits obtained by the user from the ERP system, but neglecting the attitude of the user toward the benefits of using ERP systems in general. The study will place much effort into the user perception of the general expected system benefits of ERP and the impact on the actual benefits the business obtains in a manufacturing setting within a South African context.

\section{Aim}

The study aimed to assist managers in understanding whether employees' (ERP users') expected 'general system benefits' of an ERP system affect the 'actual benefits' derived in the manufacturing industry. The study sheds light on answering what perceptions users have in general and how negative or positive perceptions influence the actual benefits of ERP. This knowledge can help managers decide how to invest business resources towards standardizing and monitoring user perceptions on ERP success factors.

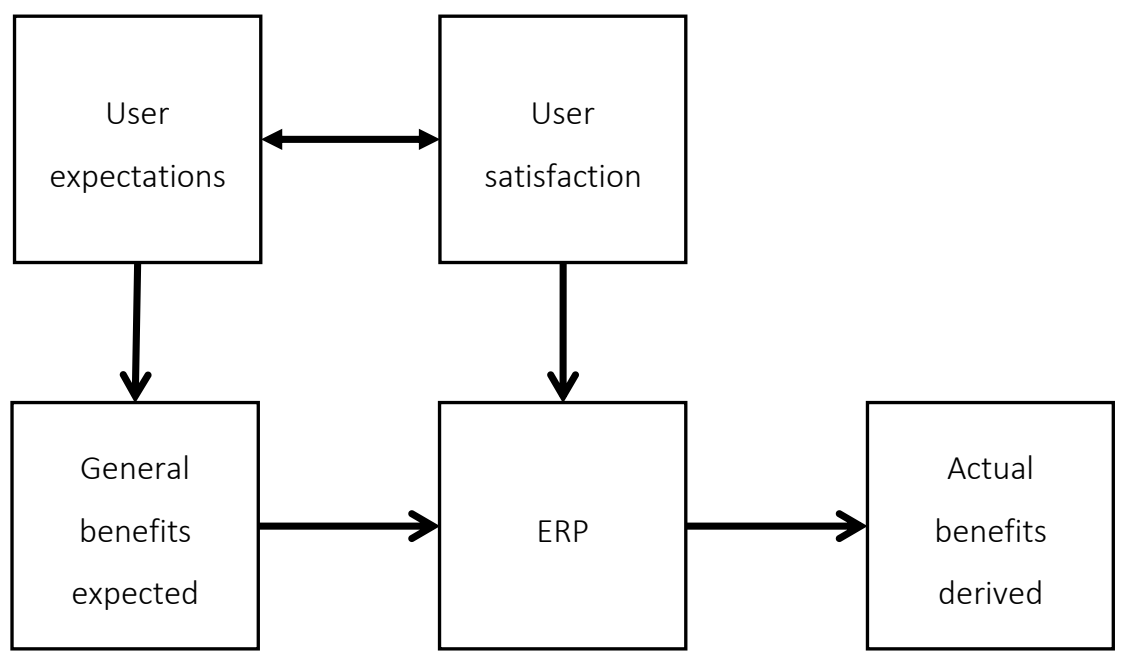

Figure 1. Conceptual framework developed from DeLone and McLean IS success model 


\section{RESEARCH METHODS AND DESIGN}

The study adopted a quantitative approach. The measurability of activities or variables is facilitated strongly by a quantitative method (Rahman, 2016). Therefore, a quantitative method allows for quick and larger samples of data collection, which, in turn, facilitates the generalization of research conclusions to the entire population (Yilmaz, 2013). This study also targeted a wide scale of respondents and, therefore, this method was seen as suitable for a study of this nature. For this study, the setting was appropriate and was chosen based on the availability of ERP system users, the resources, and time constraints. At the time the research was conducted (2018), the researcher had been an employee in a company that manufactured shoes. This company had an internal ERP system adopted more than a decade ago. Therefore, the setting was chosen to be the working place of the researcher, which was at BATA SA, a shoe manufacturing company situated in KwaZuluNatal, South Africa, with offices based in Pinetown (Durban). In the case where the target sample is the entire population, the method used is the census method (Lavrakas, 2008; ABS, 2013; Farooq, 2013).

The key components of the study, which were the research setting, the nature of the study, the research problem, the research questions and objectives, resulted in the census method being selected. The intention was to collect maximum data from all the available respondents in the research study setting. The total population was 80 individuals and 53 responded, resulting in $66 \%$ of the entire population being represented in the sample. An online questionnaire was selected, and Google Forms was used as an online tool to create the questionnaire. Once the research tool was selected, the questionnaire had to be distributed through a certain channel to reach ERP system users at the organization. The questionnaire was then sent to all employees by email, and the data collection lasted approximately 2 months.

\section{DATA ANALYSIS}

The data collection process produced the data, which required a strong data analysis to transform the raw data into useful statistics. This process was carefully undertaken to produce valid and reliable results. The collected data had nominal and ordinal data types. All ordinal data collected had a score of less than 6 rankings, and it was not normally distributed; therefore, only non-parametric data analysis techniques had to be applied. The data collection tool was effective and efficient; therefore, there were no missing data for any respondent who took part in the study. In this research, the IBM SPSS was found to be most simple to use, flexible, scalable, and it provided a larger amount of statistical analysis functions, which were required to carry out the analysis. Initially, the analysis had to begin with the exploration and presentation of data using tables and graphs. This assisted in guiding techniques to use to further analyze the data. It also allowed for the identification of findings, which could easily be identified when the data was presented visually. Descriptive statistics to the form of bar charts and graphs helped to graphically show differences of responses and perceptions between different groups. Inferential statistics were also performed to identify the relationships between variables that were useful in addressing the research problem. The exploration factor analysis (EFA) technique was applied to confirm the quality of the measuring scale. Besides, the reliability analysis was conducted through the Cronbach's Alpha reliability technique. To test for relationship, the Chi-square test and Spearman's rank correlation coefficient test were applied.

\section{RESULTS}

\subsection{Reliability}

There was a total census population of 80 employees who were requested to take part in the study, of which 53 responded by completing the questionnaire. This amounted to a $66 \%$ response rate out of a total population. The coefficient of reliability or internal consistency of the measuring scale or questionnaire was measured through the Cronbach's Apha reliability technique. The Cronbach's Alpha was 0.933 , which is greater than 0.9. As a result, the scale is confirmed to have excellent internal consistency.

\subsection{Descriptive results}

General expectations were divided into 4 groups: those who had high positive general expectations (indicated strongly agree that they expected the 
High NO Benefits Strongly Disagree

Low NO Benefits Disagree

Undecided Neutral

Low Benefits Agree

High Benefits Strongly Agree

$$
0,00 \%
$$
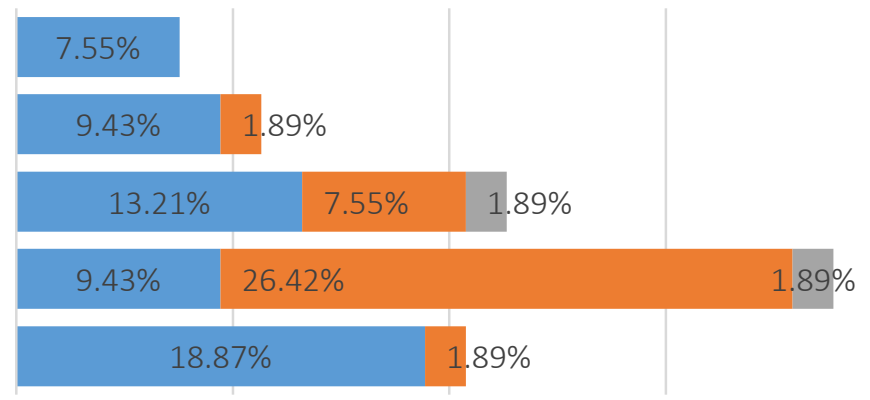

$10,00 \%$

$20,00 \%$

$30,00 \%$

$40,00 \%$

- High Positive General Expectation strongly Agree

- Low Positive General Expectation Agree

- No General Expectation Neutral

Figure 2. General expectations perceived and actual benefits derived

general benefit), low positive general expectations (agree), no general expectations (neutral), and those who had low negative general expectations (disagree). No respondents indicated high negative general expectations (strongly disagree).

\subsection{Expected general benefits perceived and actual benefits derived}

A stacked bar chart was created to graphically analyze the interaction between the perceptions of benefits generally expected and benefits derived from using the ERP system.
Figure 2 shows the perceptions of actual benefits derived between 4 groups identified by the categories of perceptions on expected general benefits. For each group, the graph depicts the perceptions of actual benefits derived by a specific number of respondents.

\subsection{Expected general benefits perceived and user satisfaction experienced}

The investigation was further conducted to identify the relationship between general expected benefits and user satisfaction of using an ERP system

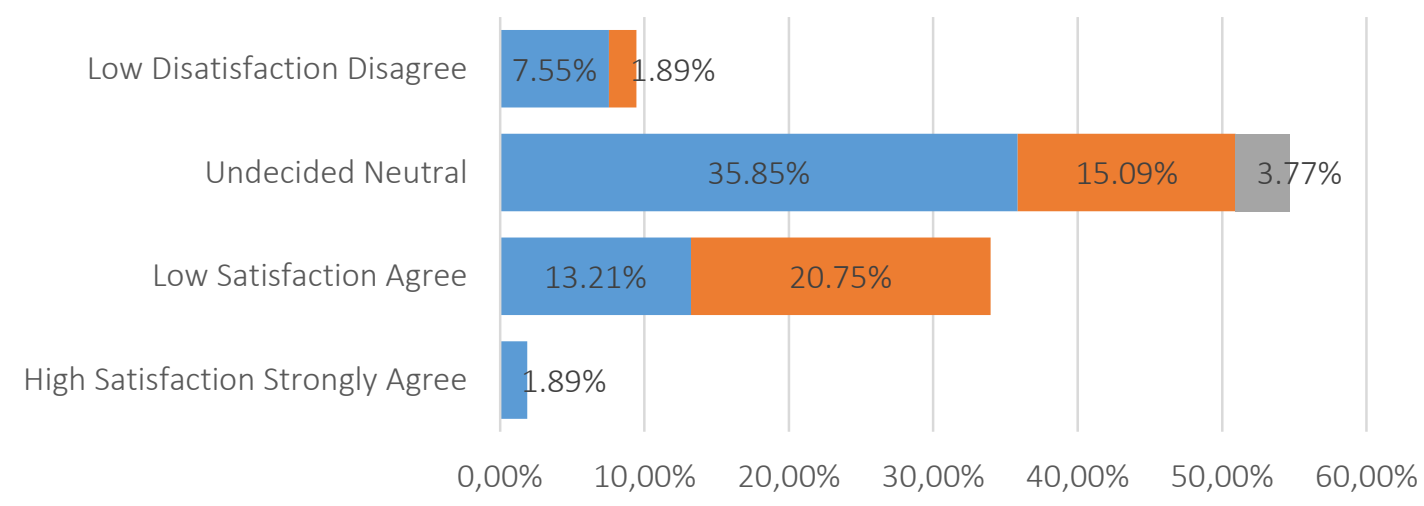

- High Positive General Expectation strongly Agree

- Low Positive General Expectation Agree

no General Expectation Neutral

Figure 3. General expectations and user satisfaction 
Table 1. Total variance explained

\begin{tabular}{|c|c|c|c|c|c|c|c|c|c|}
\hline \multirow{2}{*}{ Factor } & \multicolumn{3}{|c|}{ Initial eigenvalues } & \multicolumn{3}{|c|}{$\begin{array}{l}\text { Extraction sums of squared } \\
\text { loadings }\end{array}$} & \multicolumn{3}{|c|}{ Rotation sums of squared loadings } \\
\hline & Total & $\begin{array}{c}\% \text { of } \\
\text { variance }\end{array}$ & Cumulative \% & Total & $\begin{array}{c}\% \text { of } \\
\text { variance }\end{array}$ & Cumulative \% & Total & $\begin{array}{c}\% \text { of } \\
\text { variance }\end{array}$ & $\begin{array}{c}\text { Cumulative } \\
\%\end{array}$ \\
\hline 1 & 10.318 & 46.9 & 46.9 & 10.12 & 46.001 & 46.001 & 6.513 & 29.605 & 29.605 \\
\hline 2 & 5.609 & 25.497 & 72.397 & 5.395 & 24.523 & 70.524 & 5.477 & 24.894 & 54.5 \\
\hline 3 & 2.048 & 9.311 & 81.707 & 1.863 & 8.468 & 78.992 & 5.388 & 24.492 & 78.992 \\
\hline 4 & 0.55 & 2.5 & 84.207 & - & - & - & - & - & - \\
\hline 5 & 0.477 & 2.168 & 86.375 & - & - & - & - & - & - \\
\hline
\end{tabular}

at BATA. A stacked bar chart is represented in Figure 3. For each general expectations group, the graph depicts the perceptions of user satisfaction experienced by a specific number of respondents.

\subsection{Exploratory factor analysis}

To perform descriptive non-parametric statistical analysis, the variables had to be reduced to 3 latent variables, as depicted in Table 1 . The variables were classified into an independent variable for the construct of general expected benefits, and 2 dependent latent variables, which had the construct of actual benefits derived and user satisfaction derived by each respondent using the ERP system at BATA. The model had to be tested if it was suitable for the data; the KMO and Bartlett's test were used.

The Kaiser-Meyer-Olkin measure of sampling adequacy was 0.708 , which is a good measure. Bartlett's test of sphericity was also significant as it was less than 0.01, indicating the sufficient relationships between the variables; thus, the exploratory factor analysis could be conducted. Before extraction, there were 22 linear components in the data collected. Initially, the first factor represented $46.9 \%$ of the variance explained by the linear component. The other 2 linear components had an eigenvalue greater than 1; as a result, the linear factors were extracted, and they explained the variance of $34.808 \%$. All 3 factors before extraction explained $81.707 \%$ of the variance and were extracted; as a result, only 3 factors were extracted. The remaining 19 factors explained the total variance of $18.293 \%$, and all had eigenvalues less than 1; as a result, these factors were not extracted. To produce an optimized factor structure, the extracted factors had to be rotated, and their eigenvalues changed. The ratio sum of squared loading shows how the relative importance of the extracted factors was equalized with the fac- tor that represented most of the variance, explaining $29.605 \%$, which is significantly small from the initial $46.9 \%$. However, the second factor explained 24.894 of the variance, while the third factor explained $24.492 \%$ compared to the initial $9.311 \%$.

The loading of each variable per factor was done using rotated factor matrix. After five iterations, variables were loaded onto the respective 3 factors. The exploratory factor analysis highly confirmed the dimensionality and the validity of the questions used in the questionnaire; as a result, non-parametric descriptive statistics could be conducted. Therefore, the variables and three chosen constructs were meaningful.

\subsection{Chi-square test}

\subsubsection{General expected benefits and user satisfaction}

The Chi-square test of independence between the expectations of general benefits from an ERP system and user satisfaction was done, and the $p$-values were greater than $0.05\left(\mathrm{X}^{2}=7.965, p=0.241\right)$ and were, therefore, greater than the chosen significant level $(p=0.05)$.

Table 2. Chi-square tests between general expected benefits and user satisfaction

\begin{tabular}{l|c:c:c}
\hline & Value & df & $\begin{array}{c}\text { Asymptotic } \\
\text { significance (2-sided) }\end{array}$ \\
\hline Pearson Chi-square & $7.965^{\mathrm{a}}$ & 6 & 0.241 \\
\hline Likelihood ratio & 8.910 & 6 & 0.179 \\
\hline $\begin{array}{l}\text { Linear-by-linear } \\
\text { association }\end{array}$ & 1.372 & 1 & 0.241 \\
\hdashline N of valid cases & 53 & - & - \\
\hline
\end{tabular}

The null hypothesis was not rejected; therefore, the conclusion is made that there is no significant relationship between the expectations of general 
benefits from an ERP system and the satisfaction that respondents perceived from using it. These results imply that there is no relationship between the variables. This implies that the general expectations that users had on ERP systems did not affect their satisfaction.

\subsubsection{General expected benefits and actual benefits derived}

The association between general expected benefits from an ERP system and the actual benefits of using it was tested through Chi-square test. Table 3 shows the results of the test.

Table 3. Chi-square tests between general expected benefits and actual benefits

\begin{tabular}{l|c:c:c}
\hline & Value & df & $\begin{array}{c}\text { Asymptotic } \\
\text { significance (2-sided) }\end{array}$ \\
\hline Pearson Chi-square & $19.342^{a}$ & 8 & 0.013 \\
\hline Likelihood ratio & 22.087 & 8 & 0.005 \\
\hline Linear-by-linear & 0.796 & 1 & 0.372 \\
association & 53 & - & - \\
\hline N of valid cases & 53 & \\
\hline
\end{tabular}

The null hypothesis was rejected $(p<0.05)$, as the statistic's value was 19.342 with a probability of 0.013 . Therefore, there is a relationship between the expectations of general benefits from an ERP system and the benefit of using it.

\subsubsection{Spearman's rank correlation coefficient}

Table 5 shows the results of running the Spearman's rank correlation coefficient to determine the relationship between the perceptions of generally expected benefits with user satisfaction and actual benefits derived from using an ERP system.
The relationship between expected general benefits and user satisfaction was weak $\left(\mathrm{r}_{\mathrm{s}}=-0.217, \mathrm{n}=53\right)$. The relationship between general expected benefits and actual benefits derived was very weak $\left(\mathrm{r}_{\mathrm{s}}\right.$ $=-0.073, n=53$ ). However, a moderate and significant relationship between actual benefits derived and user satisfaction is noticeable. The Spearman's rank correlation coefficient, therefore, concluded that there is a relationship between expected benefits, user satisfaction, and actual benefits.

\section{DISCUSSION}

A moderate relationship between the actual benefits derived from the ERP system and user satisfaction was confirmed to be significant through this study. Therefore, this finding supported the DeLone and McLean IS success model (Delone \& McLean, 2003). These findings complemented the findings of Al-Jabri (2015) who discovered ERP system benefits affected user satisfaction. However, they believed that the effect was a mediating one. In their case, it meant that ERP system benefits had a mediating relationship between training and user satisfaction.

The expectations of respondents at BATA were found to be positive. This was visible because almost the entire sample indicated to believe any ERP system should offer that general benefits. No negative expectations were found by any respondent, except for one respondent out of the 53. The managers were found to have high expectations compared to their subordinates. The benefit of productivity was found to be the one that was mostly expected to be offered by any ERP system.

Table 4. Correlations matrix

\begin{tabular}{|c|c|c|c|c|c|}
\hline & & & g_exp_benefits & satisfaction & actual_benefits \\
\hline \multirow{9}{*}{ Spearman's rho } & \multirow{3}{*}{ g_exp_benefits } & Correlation coefficient & 1.000 & -0.217 & -0.073 \\
\hline & & Sig. (2-tailed) & & 0.118 & 0.605 \\
\hline & & $\mathrm{N}$ & 53 & 53 & 53 \\
\hline & \multirow{3}{*}{ satisfaction } & Correlation coefficient & -0.217 & 1.000 & $.451^{* *}$ \\
\hline & & Sig. (2-tailed) & 0.118 & & 0.001 \\
\hline & & $\mathrm{N}$ & 53 & 53 & 53 \\
\hline & \multirow{3}{*}{ actual_benefits } & Correlation coefficient & -0.073 & $.451^{* *}$ & 1.000 \\
\hline & & Sig. (2-tailed) & 0.605 & 0.001 & \\
\hline & & $\mathrm{N}$ & 53 & 53 & 53 \\
\hline
\end{tabular}

Note: ${ }^{* *}$ Correlation is significant at the 0.01 level (2-tailed). 
The results indicate that the ERP system used at BATA was challenging to use by most users; however, almost the same number of users did not feel challenged by it. A very low rate of respondents indicated that the ERP system was not very challenging to use, which implies that most respondents felt that the system was easy to use. However, they did not 'highly' perceive the easiness of using it. There was a higher rate of more experienced respondents who felt that the system was not too challenging to use as compared to those with lesser experience. These findings are in line with those produced by Babaei, Gholami, and Altafi (2015) by discovering that ERP system failure was related to users who were not experienced.

Most of the respondents were benefiting from the ERP system. The ERP system assisted the respondents to do their job better. This was the benefit that participants appreciated the most. However, they felt that the system was not updating them sufficiently regarding the organizational changes that impact their jobs. Currently, the ERP system is not entirely making the respondent's job any easier. The ERP system users who expect more of the general benefits from the system also benefited more from using it than those who do not expect more general benefits from the system. The respondents who had low expectations on general benefits were experiencing low benefits from using the ERP system as well. These findings are in line with the findings of Mitakos, Almaliotis, and Demerouti (2010) and Teittinen, Pellinen, and Järvenpää (2013). The users who expect more will perceive to benefit more as well. However, the case is different for user satisfaction.

Users with high expectations were mostly neutral in their satisfaction. This finding is not in line with that of Teittinen, Pellinen, and Järvenpää (2013) who believe that over-expectation results in underestimating the actual outcomes. These results showed that higher expectant users did not underestimate the ERP system's actual outcome compared to lower expectant users. Also, Mitakos, Almaliotis, and Demerouti's (2010) findings contradict the result of this study. They declared that the more users expect from the ERP system, the more satisfied they will be. A very low rate of high satisfaction is noticeable. Users with high expectations were not easy to satisfy as compared to users with low expectations. Very few of the participants have high satisfaction regarding the ERP system. Those who had low satisfaction are greater in numbers compared to those with high satisfaction. However, this number is still small if compared to the total response rate. User satisfaction is found to be derived mostly from the support that comes with the ERP system. These results agree with those of Shan, Li, Yao, Shi, and Ren (2014) who concluded that support provided with the ERP system is among the factors that influence user satisfaction.

\section{CONCLUSION}

This paper examined the relationship between user satisfaction and actual system benefits derived from the ERP system in a manufacturing setting. A correlation between ERP system benefits derived and user satisfaction was identified through the Spearman's rank correlation technique. Most of the respondents were found to have positive expectations regarding the general benefits that the ERP system should offer. Users with high expectations were more dissatisfied and not benefiting from the ERP system compared to the other group with low expectations. Users with more experience did not find the ERP system too challenging compared to the users who lesser experience. Users with high expectations experienced higher benefits compared to those with low expectations. Employees should be educated to have realistic general expectations of ERP systems, while the ERP system should be developed with the priority of conforming to user jobs and the simplification thereof. 


\section{RECOMMENDATIONS}

Based on the literature review, data analysis, and discussion, the following recommendations are made:

- Recommendation 1: When business organizations look for new employees who are ERP system users, their selection process should target new employees who possess low expectations because they are more likely to perceive more benefits compared to those who possess high, unrealistic expectations. Besides, managers should subsequently provide training to new employees with the objectives to promote realistic expectations and proper use.

- Recommendation 2: In the case of adopting a new ERP system or upgrading it, the buyers should have a comprehensive plan for benefits realization. They should ensure that the new ERP system prioritizes productivity and is aligned to simplify the jobs of users.

- Recommendation 3: ERP system designers are encouraged to prioritize productivity and simplify user jobs when they are improving and designing new ERP systems. They should create ERP systems that conform to user jobs as opposed to users conforming to the system.

- Recommendation 4: IT managers should prioritize the service quality of the support their department will be providing daily and try their best to prioritize the maintenance and upgrading of the ERP system.

\section{AUTHOR CONTRIBUTIONS}

Conceptualization: Vukani Cosmos Xulu, Sachin Suknunan.

Data curation: Vukani Cosmos Xulu.

Formal analysis: Vukani Cosmos Xulu.

Investigation: Vukani Cosmos Xulu, Sachin Suknunan.

Methodology: Vukani Cosmos Xulu, Sachin Suknunan.

Project administration: Vukani Cosmos Xulu.

Resources: Vukani Cosmos Xulu.

Software: Vukani Cosmos Xulu.

Supervision: Sachin Suknunan.

Validation: Vukani Cosmos Xulu.

Visualization: Vukani Cosmos Xulu.

Writing - original draft: Vukani Cosmos Xulu.

Writing - review \& editing: Sachin Suknunan.

\section{ACKNOWLEDGMENTS}

The authors would like to sincerely thank all respondents who assisted in completing this research study. The authors would like to specifically thank Mr Mike Cooper, the IT manager at BATA (SA), whose help enabled the study to be conducted at BATA.

\section{REFERENCES}

1. Abd Elmonem, M. A., Nasr, E. S., \& Geith, M. H. (2016). Benefits and challenges of cloud ERP systems - A systematic literature review. Future Computing and Informatics Journal, 1(1-2), 1-9. https://doi.org/10.1016/j. fcij.2017.03.003
2. Aggelidis, V. P., \& Chatzoglou, P. D. (2012). Hospital information systems: measuring end user computing satisfaction (EUCS). Journal of Biomedical Informatics, 45(3), 566-579. https://doi. org/10.1016/j.jbi.2012.02.009
3. Al-Jabri, I. M. (2015). Antecedents of user satisfaction with ERP systems: mediation analyses. Kybernetes, 44(1), 107-123. https:// doi.org/10.1108/K-05-2014-0101

4. Al-Jabri, I. M., \& Roztocki, N. (2015). Adoption of ERP systems: 
Does information transparency matter? Telematics and Informatics, 32(2), 300-310. https://doi. org/10.1016/j.tele.2014.09.005

5. Australian Bureau of Statistics (ABS). (2013). Census and Sample. Retrieved from http://www.abs. gov.au/websitedbs/a3121120.nsf/ home/statistical+language++ census+and+sample (accessed on November 26, 2018).

6. Babaei, M., Gholami, Z., \& Altafi, S. (2015). Challenges of Enterprise Resource Planning implementation in Iran large organizations. Information Systems, 54, 15-27. https://doi.org/10.1016/j. is. 2015.05 .003

7. Badewi, A., \& Shehab, E. (2016). The impact of organizational project benefits management governance on ERP project success: Neoinstitutional theory perspective. JPMA International Journal of Project Management, 34(3), 412-428. https://doi.org/10.1016/j.ijproman.2015.12.002

8. Badewi, A., Shehab, E., Zeng, J., \& Mohamad, M. (2017). ERP Benefits Capability Framework: Orchestration Theory Perspective. Business Process Management Journal, 24(1), 266-294. https://doi. org/10.1108/BPMJ-11-2015-0162

9. Delone, W. H., \& McLean, E. R. (2003). The DeLone and McLean model of information systems success: a ten-year update. Journal of Management Information Systems, 19(4), 9-30. https://doi.org/10.1080/ 07421222.2003.11045748

10. Dwivedi, Y. K., Wastell, D., Laumer, S., Henriksen, H. Z., Myers, M. D., Bunker, D., Elbanna, A., Ravishankar, M. N., \& Srivastava, S. C. (2015). Research on information systems failures and successes: Status update and future directions. Information Systems Frontiers, 17(1) 143-157. https://doi.org/10.1007/ s10796-014-9500-y

11. Esteves, J. (2009). A benefits realisation road-map framework for ERP usage in small and mediumsized enterprises. Journal of Enterprise Information Management, 22(1-2), 25-35. https://doi. org/10.1108/17410390910922804

12. Farooq, U. (2013). What is Census Method of Data Collection, Advantages \& Disadvantages.
Retrieved from http://www. studylecturenotes.com/socialresearch-methodology/what-iscensus-method-of-data-collectionadvantages-disadvantages (accessed on November 26, 2018).

13. Kadir, R. A., Ismail, N. A., \& Yatin, S. F. M. (2015). The Benefits of Implementing ERP System in Telecommunications. Procedia Social and Behavioral Sciences, 211, 1216-1222. https://doi.org/10.1016/j. sbspro.2015.11.162

14. Kanellou, A., \& Spathis, C. (2013). Accounting benefits and satisfaction in an ERP environment. International Journal of Accounting Information Systems, 14(3), 209-234. https://doi.org/10.1016/j.accinf.2012.12.002

15. Lavrakas, P. J. (2008). Encyclopedia of Survey Research Methods. SAGE Publications, Inc. http://dx.doi. org/10.4135/9781412963947

16. Maier, C., Laumer, S., \& Weinert, C. (2015). Enterprise resource planning systems induced stress: a comparative empirical analysis with young and elderly SAP users. In Wirtschaftsinformatik Proceedings (pp. 1391-1406). Retrieved from https://aisel.aisnet.org/wi2015/93/

17. May, J., Dhillon, G. \& Caldeira, M. 2013. Defining value-based objectives for ERP systems planning. Decision Support Systems, 55(1), 98-109. https://doi.org/10.1016/j. dss.2012.12.036

18. Mitakos, T., Almaliotis, I., \& Demerouti, A. (2010). An Auditing Approach for ERP Systems Examining Human Factors that Influence ERP User Satisfaction. Informatica Economica, 14(1), 78-92. Retrieved from https:// www.researchgate.net/publication/43121546_An_Auditing_Approach_for_ERP_Systems_Examining_Human_Factors_that_Influence_ERP_User_Satisfaction

19. Rahman, M. S. (2016). The Advantages and Disadvantages of Using Qualitative and Quantitative Approaches and Methods in Language "Testing and Assessment" Research: A Literature Review. Journal of Education and Learning, 6(1), 102-112. http://dx.doi. org/10.5539/jel.v6n1p102

20. Rana, N. P., Dwivedi, Y. K., Williams, M. D., \& Weerakkody, V.
(2015). Investigating success of an e-government initiative: Validation of an integrated IS success model. Information Systems Frontiers, 17, 127-142. https://doi.org/10.1007/ s10796-014-9504-7

21. Salahuddin, L., \& Ismail, Z. (2015). Classification of antecedents towards safety use of health information technology: A systematic review. International Journal of Medical Informatics, 84(11), 877-891. https://doi. org/10.1016/j.ijmedinf.2015.07.004

22. Shan, S., Li, C., Yao, W., Shi, J., \& Ren, J. (2014). An Empirical Study on Critical Factors Affecting Employee Satisfaction. Systems Research and Behavioral Science, 31(3), 447-460. https://doi. org/10.1002/sres.2284

23. Steinhueser, M., Richter, A., \& Smolnik, S. (2015). How to bridge the boundary? Determinants of inter-organizational social software usage. Electron Markets, 25, 267-281. https://doi.org/10.1007/s12525-0150192-z

24. Teittinen, H., Pellinen, J., \& Järvenpää, M. (2013). ERP in action Challenges and benefits for management control in SME context. International Journal of Accounting Information Systems, 14(4), 278-296. https://doi. org/10.1016/j.accinf.2012.03.004

25. Vaezi, R., Mills, A., Chin, W., \& Zafar, H. (2016). User Satisfaction Research in Information Systems: Historical Roots and Approaches. Communications of the Association for Information Systems, 38, 501-532. Retrieved from https://pdfs.semanticscholar.org/f5c4/a19dfcc9787de37feea8882f0234aeba9f84.pdf

26. Venkataiah, D., \& Sagi, S. (2012). Relationship between Kaizen Events and Perceived Quality Performance in Indian Automobile Industry. International Journal of Management \& Business Studies, 2(1), 25-28. Retrieved from http:// www.ijmbs.com/21/venkataiah.pdf

27. Yilmaz, K. (2013). Comparison of quantitative and qualitative research traditions: Epistemological, theoretical, and methodological differences. European Journal of Education, 48(2), 311-325. https:// doi.org/10.1111/ejed.12014 